\title{
Impact of fertilizer priming on seed germination behavior and vigor of maize
}

\author{
Amir Zaman Khan ${ }^{1}, \operatorname{Imran}^{1 *}$, Asim Muhammad ${ }^{1}$, Aiman Khali1 ${ }^{1}$, Hasina \\ Gul $^{1}$, Habib Akbar ${ }^{1}$ and Said Wahab ${ }^{2}$ \\ 1. Department of Agronomy, University of Agriculture, Peshawar, Pakistan \\ 2. Department of Food Science, University of Agriculture, Peshawar, Pakistan \\ *Corresponding author's email: imranagrarian@aup.edu.pk \\ Citation \\ Amir Zaman Khan, Imran, Asim Muhammad, Aiman Khalil, Hasina Gul, Habib Akbar and Said Wahab. Impact of \\ fertilizer priming on seed germination behavior and vigor of maize. Pure and Applied Biology. Vol. 5, Issue 4, \\ pp744-751. http://dx.doi.org/10.19045/bspab.2016.50093
}

\begin{tabular}{llll}
\hline Received: $12 / 02 / 2016$ & Revised: $13 / 07 / 2016$ & Accepted: 20/07/2016 & Online First: 08/08/2016 \\
\hline
\end{tabular}

\section{Abstract}

Laboratory experiments were conducted to examine the efficacy of fertilizer priming on seed germination behavior and vigor of two maize cultivars "Azam and Phari" at Agronomy Research Laboratory, University of Agriculture, Peshawar- Pakistan during 2015. Studied treatments include hydropriming (distilled water) and osmopriming with Calcium Ammonium Nitrate (CAN) at $0.5 \%$ for 24 hours. Non primed seed were used as control. Data were recorded on germination and vigor parameters according to standard procedures. Results showed that both hydro and osmo-priming significantly improved germination $\%$, mean germination time, germination index, plumule and radical length, seedling fresh and dry weight of both cultivars as compared to control treatment. Cultivar Azam performed better in all germination and vigor attributes than Phari. It was concluded that both hydro and osmopriming with Calcium Ammonium Nitrate (CAN) at $0.5 \%$ for 24 hours are practical approaches for improving growth and vigor of maize crop under harsh environment.

Keywords: Seed priming; Fertilizer priming; Hydropriming; Germination; Vigor attributes

\section{Introduction}

Maize is a multipurpose crop and widely grown for human and animal nutrition and used for agro-industrial purposes worldwide [1]. Its grain is a rich source of starch (72\%), vitamins A \& B (3-5\%), proteins (10\%), oil content (4.8\%), $5.8 \%$ fiber, $3.0 \%$ sugar and $1.7 \%$ ash. In spite of high yield potential of maize, its yield per unit area is low as compare to other advanced countries of the world. In Pakistan maize was cultivated over an area of (1130) thousand hectares with an annual production of (4695) thousand tones with an average yield of (4155) $\mathrm{kg} \mathrm{ha}^{-1}$ (PES, 2014-15). In KP it was grown on about (470.9) thousand hectares with production of (914.8) thousand tons annually. The average yield of maize in KP was (1943) $\mathrm{kg} \mathrm{ha}^{-1}$ [2]. In KP, maize crop grown in Peshawar, Mardan, Swabi, Malakand, Charsada, Haripur include irrigated belt of D.I.Khan, Bannu and Kohat [3]. In semi-arid tropic of Khyber Pukhtunkhwa, maize production is widely limited by poor stand establishment and nutrient deficiencies. Poor seed germination and seedling establishment are determined by many factors including quality of seeds and environmental factors. Physical, chemical and biological factors within the environment influence seed vigor, germination speed and seedling growth. 
Seed priming is a pre-sowing strategy for influencing seedling development by enhancing pre germination metabolic activity prior to emergence of the radical and generally enhances germination rate and plant performance. Seed priming has been shown to improve seed performance under sub-optimal temperature conditions [4]. Germination and emergence both are sensitive to adverse soil conditions [5]. It has been reported that on-farm trials of priming in maize, increase yield up to $6 \%$ (non-primed yield $4.4 \mathrm{t} \mathrm{ha}^{-1}$; [6] and $33 \%$ (non-primed yield $3.1 \mathrm{t} \mathrm{ha}^{-1}$; [7] were recorded. Nitrate solutions produce more vigorous seedling and higher dry matter accumulation and root length as compared to non-primed seeds. Seed priming treatment can lead to better germination and establishment in many crops such as maize, wheat, rice, canola [8]. Priming treatments help in faster seedling emergence and increase seedling shoot fresh weight as compared to non-primed seeds. Many researchers have reported that seed priming in rapeseed improved germination percentage and increased seedling establishment [9, 10]. Seed priming had positive effect on germination characteristics of other crops, such as corn [11, 12], popcorn (Zea mays sacharum L) [13], and cotton (Gossypum hirsutum L.) [14, 15] reported that nutripriming in $4 \%$ mono ammonium phosphate can improve effective tillers and grain yield of direct sown rice. Keeping in view the significance of seed priming, present study was designed to evaluate hydro and fertilizer priming technique on germination behavior and vigor of maize cultivars under laboratory conditions.

\section{Materials and methods}

A laboratory experiment entitle "Impact of fertilizer priming on seed germination behavior and vigor of maize" was conducted at Agronomy Research laboratory,
University of Agriculture Peshawar, Pakistan, during 2015. The experiment was laid out in completely randomized (CRD) design having two factors. Factor "A" was consist of maize cultivars "Azam and Phari" while factor "B" was consist on three priming treatments i.e: hydro-priming (distilled water), osmo-priming (CAN @ $0.5 \%$ ) and dry seed/control. Seeds of both cultivars were obtained from the Research Farm, Agriculture University, were surface sterilized in $10 \%$ sodium hypochlorite solution for 10 minutes, then rinsed with sterilized water and air-dried at room temperature closely to original moisture level. Seeds of both cultivars were subjected to 24 hours priming in distilled water and Calcium Ammonium Nitrate solution@ $0.5 \%$. Non primed seeds were used as control. The solution to seed ratio was 1:2.5 for all the treatments. Germination potential of controlled and treated seeds was estimated in accordance with (AOSA, 1983).To test seed germination and seedling vigor, four replicates of 25 seeds were germinated in plastic trays with moist blotting paper, replicated four times and were placed in growth chamber at $25^{\circ} \mathrm{C}$ temperature for 7 days. A seed was considered to have germinated when coleoptile and radical lengths have reached $2 \mathrm{~mm}$. Counts of germinating seeds were made daily, starting on the first day of imbibition and terminated when maximum germination was achieved. The time to reach $50 \%$ germination $\left(\mathrm{T}_{50}\right)$ of final germination was calculated according to the following formula of Coolbear et al. (1984):

$$
T_{50=} t_{i+} \frac{\left[\frac{N}{2}-n_{i}\right]\left(t_{j}-t_{i}\right)}{n_{j-} n_{i}}
$$

Where $\mathrm{N}$ is the final number of germination and ni, nj cumulative number of seeds germinated by adjacent counts at time ti and tj when $n i<N / 2<$ nj.

Germination index (GI) was calculated according to AOSA (1983) formula: 
$G 1=\frac{\text { No. of germinated seeds at first count }}{\text { Days of first count }}+--+\frac{\text { No. of germinated seeds at final count }}{\text { Days of finalcount }}$

\section{Seedling emergence}

Control and treated seeds were sown in plastic trays (25 in each) having moist sand, replicated three times and were placed in growth chamber at $25^{\circ} \mathrm{C}$ temperature in completely randomized design. Emergence was recorded daily according to AOSA rules (2009). Mean emergence time (MET) was calculated according to the equation of Ellis and Roberts (1981) as under:

\section{$M E T=\Sigma D n / \Sigma n$}

Where $\mathrm{n}$ is the number of seeds, which were germinated on day D and D is the number of days counted from the beginning of emergence. The plants were harvested 12 days after planting and seedling vigor data were recorded according to AOSA (2009).

\section{Measurement of root and shoot length}

Root and shoot length of all 25 seedlings were measured after 12 days of experiment. It was measured with a measuring scale and expressed in centimeters. These seedlings were kept in brown paper and weighed the fresh weight first and were died in oven at $70^{\circ} \mathrm{C}$ for 48 hours to record the dry weight. These were measured with electronic balance and expressed in gram.

\section{Statistical analysis}

The data was analyzed statistically using analysis of variance techniques appropriate for Completely Randomized Deign on computer based software "Statistix" version No (8.1). The treatments mean were compared using least significant difference (LSD) test at 0.05 level of probability [22].

\section{Results}

\section{Germination (\%)}

Perusal of the data shows that seed priming treatments significantly affected the germination of both cultivars. Whereas the interaction between priming treatments and varieties $(\mathrm{P} \times \mathrm{V})$ was found non-significant (figure 1). Osmo priming enhanced germination percentage as compared to other priming treatments. Optimum germination percentage $(82 \%)$ was observed in osmo primed seed followed by dry/nonprimed seed (64\%). Minimum germination percentage $(64 \%)$ was noted when the seeds were primed with water (hydro-priming). Cultivars positively responded to priming treatments. Optimum germination percentage $(73 \%)$ was given by cultivar "Azam" followed by cultivar "Phari" having lowest germination percentage (64\%).

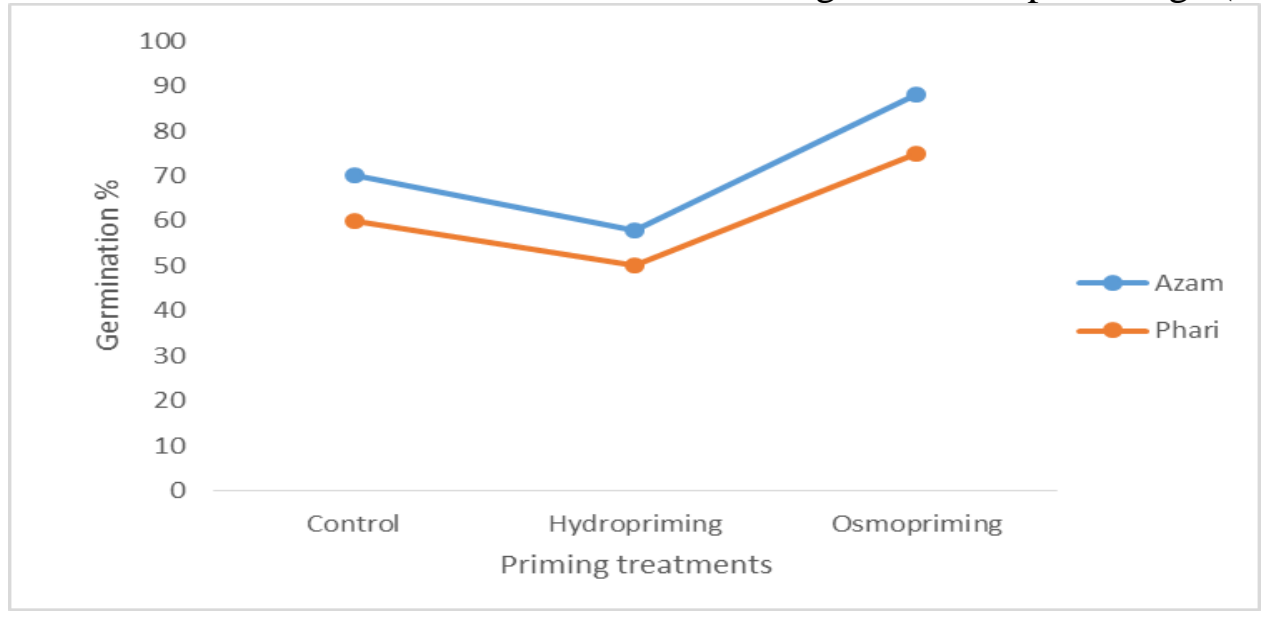

Figure 1. Germination \% of maize influenced by priming treatments

\section{Germination index and mean germination time (GI, MGT)}

Priming treatments significantly affected the germination vigor of both cultivars. The response of both cultivars to different priming techniques approximately was similar. Earlier germination was recorded for hydroprimed seeds and mean 
germination time (MGT). Seeds hydroprimed had lowest values and MGT was observed in osmoprimed seeds which were subjected to Calcium Ammonium Nitrate (CAN) at $0.5 \%$ for 24-hours solution. All the seed treatments resulted in higher MGT, being highest in CAN priming. Maximum GI and were noted in untreated seeds, all the seed treatments resulted in lower values of GI.

\section{Plumule length $(\mathrm{cm})$}

Data regarding plumule length $(\mathrm{cm})$ are presented in Figure 2. Analysis of the data showed that plumule length $(\mathrm{cm})$ was significantly affected by priming treatments and varieties. Interaction between priming treatments and varieties $(\mathrm{P} \times \mathrm{V})$ was found non-significant. Maximum plumule length $(3.34 \mathrm{~cm})$ was noted in seeds treated with CAN $0.5 \%$ followed by non-primed seed $(2.73 \mathrm{~cm})$. Minimum plumule length $(2.25$ $\mathrm{cm})$ was produced by seeds primed with water. Non primed seed showed better performance than hydro primed seed in term of plumule length. Similarly varieties responded positively to priming and optimum plumule length was noted in cultivar "Azam" having $2.95 \mathrm{~cm}$ plumule length followed by cultivar "Phari" $(2.60$ $\mathrm{cm})$ respectively.

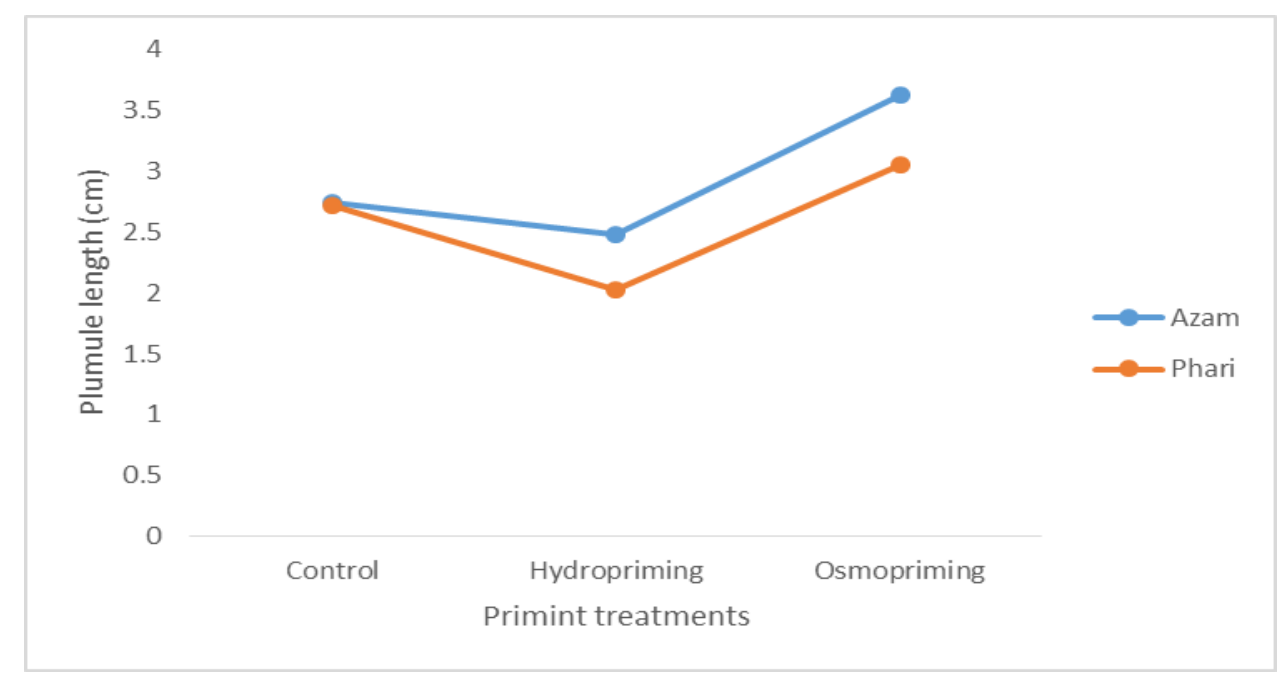

Figure 2. Plumule length $(\mathrm{cm})$ of maize influenced by priming treatments

\section{Radicle length (cm)}

The influence of priming on root length of cultivars are presented in Figure 3. Perusal of the data revealed that priming treatments and interaction between priming and varieties $(\mathrm{P} \times \mathrm{V})$ had significant effect on root length while varieties had nonsignificant effect in this order. Dry seed/control treatment (non-primed seed) shows highest radicle length $(5.95 \mathrm{~cm})$ as compared to hydro and osmo-priming having at par radicle length 4.47 and 4.65 $\mathrm{cm}$ respectively. Mean data of varieties indicates that Phari have maximum root length $(5.11 \mathrm{~cm})$ than Azam $(4.95 \mathrm{~cm})$. The combine effects of priming and varieties data indicate significant $(\mathrm{P} \leq 0.05)$ on root length. Phari variety maximum root length $(6.75 \mathrm{~cm})$ under control treatment of priming than hydro and chemo treatments of priming. In case of interaction cultivar "phari" showed optimum radicle length $(6.75 \mathrm{~cm})$ as compared to cultivar "Azam" in control treatment. As seeds were primed with water the radicle length was observed with short length as compared to CAN 
primed seed. Cultivar “ Azam” showed relatively better performance than "Phari" in term of radicle length when primed with water and CAN at $0.5 \%$ while highest radicle length $(6.75 \mathrm{~cm})$ was gave by cultivar " Phari" when seeds were non primed.

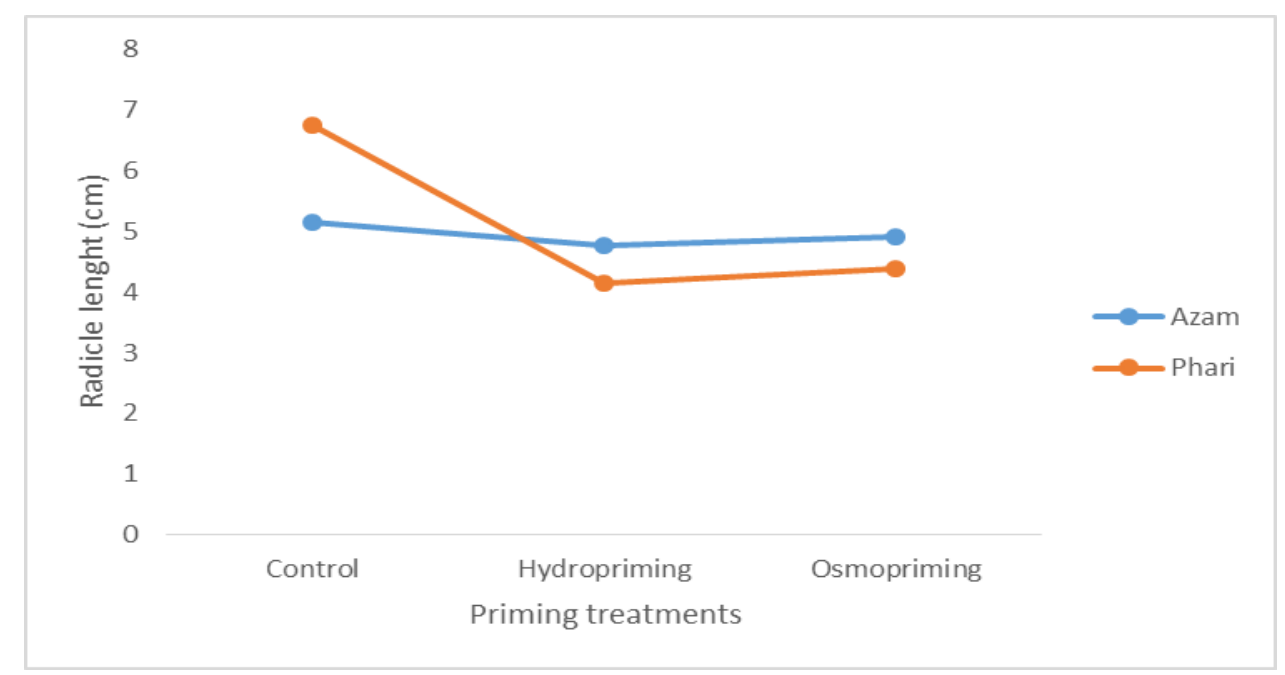

Figure 1. Radicle length $(\mathrm{cm})$ of maize influenced by priming treatments

Fresh and dry weight of seedling (mg)

Dry weight of seedling (DWS) was nonsignificant at all the treatments whereas perusal of the data indicated that priming had significant effect on SFW of maize whereas varieties and interaction between priming and varieties ( $\mathrm{P} \times \mathrm{V}$ ) had nonsignificant effect of SFW. Mean data showed that FDW was responded positively to priming treatments and significant difference was found in SFW of all the priming treatments. Highest SFW (3533.8 mg) was produced by the seeds primed with chemical followed by non-primed seed (2811.2 mg). The lowest SFW (1178.8 mg) was recorded when the seeds were treated with priming 


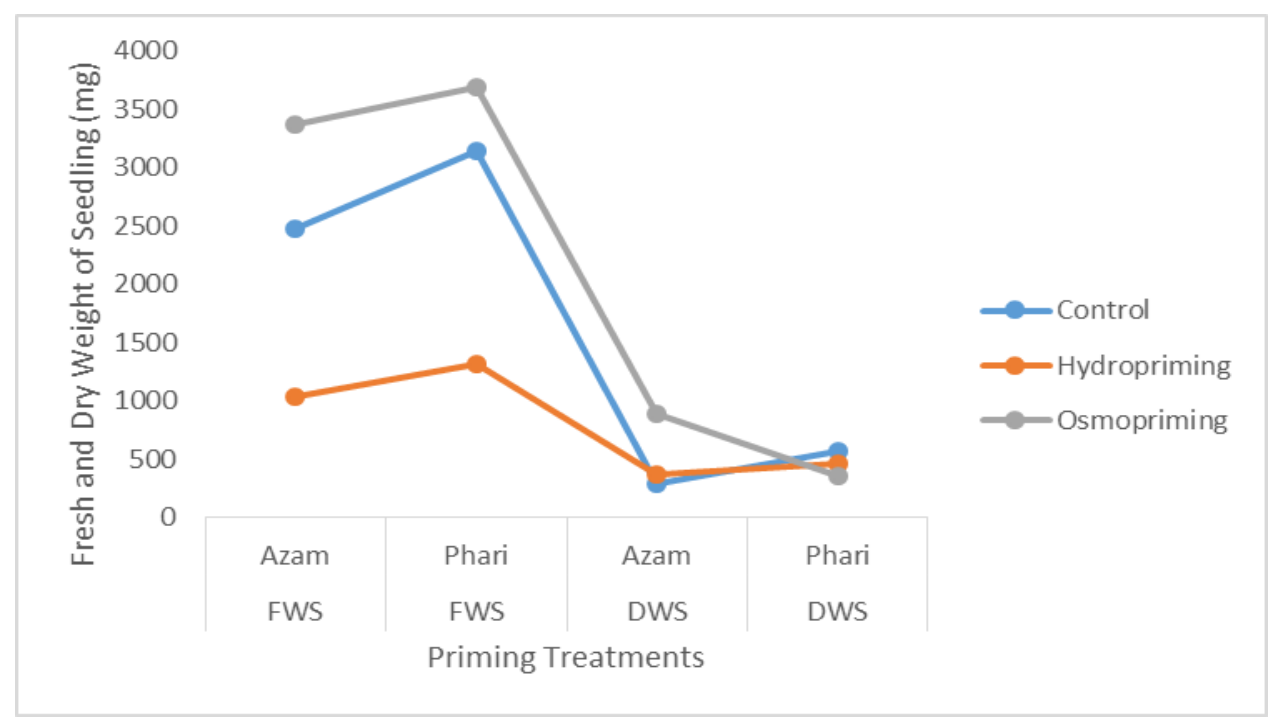

Figure 2. Fresh and dry weight of seedling (mg) influenced by priming treatments

\section{Discussion}

The effect of osmo priming has high germination $\%$ as compared to control and hydro priming. Cultivar Azam have maximum germination $\%$ than Phari. Germination \% was significantly affected by priming and varieties. Similar results was observed by [15] reported that germination and early growth of inbred lines of maize were enhance by priming. This might be due to chemical changes in seeds and might be due to enzyme activation by various priming techniques. [16] Reported that dry seeds took 10 day to reach $50 \%$ emergence while water and osmo primed seeds reached $50 \%$ emergence in five days. They concluded that osmo primed seeds (2\% $\mathrm{Zn}$ solution and $1 \%$ $\mathrm{P}$ solution) produce superior seed emergence as compared to dry seeds in control condition. $[12,13,18]$ also concluded the same findings of priming for crop stand, germination and emergence. Plumule length of maize cultivars significantly affected by priming. $[2,3,16]$ also noted the same results of on-farm seed soaking on emergence. Maximum shoot length was recorded for osmo priming $(81.625 \mathrm{~cm})$. $[12,19]$ also recorded that priming treatment significantly affect fresh weight, shoot length, number of roots, root length, and seedling growth of three maize varieties. Earlier germination was recorded for hydroprimed seeds and mean germination time (MGT). Seeds hydroprimed had lowest values and MGT was observed in osmoprimed seeds which were subjected to Calcium Ammonium Nitrate (CAN) at $0.5 \%$ for 24-hours solution. All the seed treatments resulted in higher MGT, being highest in CAN priming. Maximum GI and were noted in untreated seeds, all the seed treatments resulted in lower values of GI. The influence of priming showed significant effect on radical length. Control treatment showed highest root length as compared to hydro priming and osmo priming. Similarly the interaction of priming and varieties showed significant effect on radical length. $[17,18,21]$ studied the osmo priming of $\mathrm{Ca}$ and $\mathrm{Zn}$ combination on maize and confirmed that seeds behavior and germination was optimized with fertilizer treatments. Similar results was founded by [13]. They examined that increase in germination rate, seed vigor, seedling fresh weight, seedling height and root length and number was recorded when the seeds primed with fertilizers. [17, 19, 23] also reported the significant effect of 
priming on three varieties of maize. They divulge that fresh weight, shoot length, number of roots and root length was enhanced with various priming. Seedling fresh weight of maize indicates that osmo priming optimize internal behavior of the concern enzymes involved in germination process and other seed vigor attributes stimulated by priming treatments. The results of this experiment agreed with the finding of $[14,15,18,24]$ who reported that priming increase the germination rate, seed vigor, seedling fresh weight, seedling height and root length and number.

\section{Conclusions}

The overall results of the present investigations lead us to the conclusion that both hydro and osmopriming with calcium ammonium nitrate (CAN) enhanced germination behavior and vigor of both cultivars. However, fertilizer priming with $0.5 \%$ Calcium Ammonium Nitrate for 24 hours gave best results as compared to hydropriming. Cultivar Azam performed better over Phari in all studied parameters.

\section{Authors' contributions}

Conceived and designed the experiments: AZ Khan, Performed the experiments: A Khalil \& H Gul, Analyzed the data: Imran \& A Muhammad, Contributed reagents/ materials/ analysis tools: $\mathrm{H}$ Akbar \& S Wahab, Wrote the paper: AZ Khan \& Imran.

\section{References}

1. Association of Official Seed Analysis (AOSA) (2001).Rules for testing seeds. J Seed Technology,12:1-112

2. Arif M, Ali S, Shah A, Javed N \& Rashid A (2005). Seed priming Maize for improving emergence and seedling growth. Sarhad J Agric. 21:539-54.

3. Arif M, Kakar KM, Jan MT \& Younas M (2003). Seed soaking enhance emergence of mung bean. Sarhad $J$ Agric. 19:439-441.

4. Ajirloo AR, Shaban M \& Moghanloo GD (2013). Effect of priming methods on emergence and seedling growth of maize (Zea mayze L.). Intl J Farm \& Alli Sci. 2 (18): 658-661.

5. Basra AS, Dhillon R \& Malik CP (1989). Influence of seed treatment with plant growth regulators on metabolic alterations ofgerminating maize embryos under stressing temperature regimes. Annu Rev Bot. 64: 37-41.

6. Basra AS, Ullah E, Warraich EA, Cheema MA \& Afzal I (2003). Effect of storage on growth And yield of primed canola (Brassica napus) seeds. International J Food Agric Biol. 2:117120.

7. Basra SMA, Farooq M, Tabassum R \& Ahmad N (2005). Physiological and biochemical Aspect of pre-sowing seed treatment in fine rice (Oryza sativa L.) Seed Sci Technol. 33: 623-628.

8. Chiu KY, Chen CL, Sung JM ( 2002). Effect of priming tempera-ture on storability of Primed sh-2 sweet corn seed. Crop Sci. 42: 1996-2003.

9. Dezfuli PM, Sharif-Zadeh F \& Janmohammadi M (2008). Influence of priming techniques On seed germination behavior of maize inbred lines (Zea mays L.). ARPN Journal of Agricultural and Biological Science. 3(3) May 2008.

10. Harris D, Rashid A, Hollington PA, Jasi L \& Riches C (2002). Prospects of improving Maize yields with 'on farm' seed priming. in sustainable maize production systems for nepal. (eds n.p. rajbhandari, j. k. ransom. adikhari and a. f. e. palmer). kathmandu: narc and the international maize and wheat improvement center(CIMMYT). pp180-185

11. Harris D, Raghuwanshi BS, Gangwar JS, Singh SC, Joshi KD, Rashid A \& Hollington PA (2001a). Participatory evaluation by farmers of on-farm seed priming in wheat in India, Nepal and 
Pakistan. Experimental Agriculture 37:403-415.

12. Huffaker A, Kaplan F, Vaughan MM, Dafoe NJ, Ni X, Rocca JR, Alborn HT, Peter EA \& Schmelz EA (2011). Novel acidic sesquiterpenoids constitute a dominant Classof pathogen-induced phytoalexins in maize. Plant physiol 156(4): 2082-2097.

13. Hong F, Chengcang MA, Hong FC, Ma CC, Wang XM \& Ji GM (1996). Effect of $\mathrm{Ca}$ and $\mathrm{Zn}$ on seed vigor and some enzyme activities during seed germination of maize plant Physi comm. 32:110-112.

14. Kalita U, Suhrawardy J \& Das JR (2002). Effect of seed priming with potassium salt and potassium levels on growth and yield of direct seeded summer rice (Oryza sativa L.) under rainfed upland condition. Indian Journal of Hill Farming. 15: 50-53.

15. Lin JM \& Sung JM (2001). Pre-sowing treatments for improving emergence of bitter gourd seedlings under optimal and sub-optimal temperatures. Seed Science and Technology, 29(1):39 -50.

16. MNFSR (2013-14). Ministry of National Food Security and Research.Govt.of Pakistan, Economic Wing, Islambad.

17. Murungu FS, Nyamugafata $P$, Chiduza C, Clark LJ \& Whalley WR (2003). Effects of seed priming aggregate size and soilmatric potential on emergence of cotton (Gossypium hirsutumL. and maize (Zea mays L.). Soil Tillage Res. 74: 161-168.

18. Mohammadi GR (2009). The influence of $\mathrm{NaCl}$ priming on seed germination and seedling Growt of canola (Brassica napusL.) under salinity conditions. AmEurasian J Agric Environ Sci. 5: 696700.

19. Murungu FS, Chiduza C, Nyamugafata P, Clark LJ, Whalley WR \& Finch WE (2004). Effect of on-farm seed priming on consecutive daily sowing Occasions on the emergence and growth of maize in semi-arid Zimbabwe. Field Crops Res, 89:49-57.

20. Nabi G, Mullins CE, Montemayor MB \& Akhtar MS (2001). Germination and emergence of irrigated cotton in pakistan in relation to sowing depth and physical properties of the seedbed. Soil and tillage research, 59:33-44.

21. PES (2014-15). Pakistan Economic Survey.Economic Adviser's Wing, Finance Division, Govt. of Pakistan, Islambad.

22. Steel RGD \& Torrie JH (1997). Principles and procedures of statistics. A Biometrical Approach. McGraw Hill, New York.

23. Shah SR (2007). Effect Of Seed Priming On Yield Components Of Maize.M.Sc(Hons) Thesis, Deptt Of Agron ,NWFP Agric Univ, Peshawar, Pakistan. Pp.1-73.

24. Toselli ME \& Casenave EC (2003). Water content and the effectiveness of hydro and osmotic, priming of cotton seeds. Seed Sci Technol, 31: 727-735.

25. Ellis RA \& Roberts EH (1981). The quantification of ageing and survival in orthodox seeds. Seed Sci Technol, 9: 373-409. 